\title{
Learning from the literature on community development for the implementation of community renewables in South Africa
}

\author{
Holle L. Wlokas ${ }^{1 \star}$, Peter Westoby ${ }^{2}$, Sue Soal \\ 1. University of Cape Town, Energy Research Centre, Private Bag X3, Rondebosch 7701, South Africa \\ 2. University of Queensland, School of Social Science, St Lucia QLD 4072, Australia; Development Support Unit, \\ University of the Free State, P.O. Box 339, Bloemfontein 9300, South Africa
}

\section{Abstract}

Implementation of large-scale wind, solar and hydro projects in South African communities is intended to contribute to local economic development. Government policy, through the Renewable Energy Independent Power Producer Procurement Programme (REIPPPP), obliges energy companies to share revenue and ownership with local communities, thus providing renewable energy companies with a significant opportunity to position the industry as a significant contributor to community development and thus to the country's transformation and development agenda. This investigation draws on policy documents and interview data to establish that the policy's lack of appreciation for existing community development tradition and frameworks, commonly applied in South African development policy and programmes, has weakened its potential. Furthermore, it theoretically positions the emerging practice employed by the renewables industry in the implementation of the REIPPPP requirements, and outlines how existing academic and practical knowl-
\end{abstract}

edge about community development and companycommunity relations can provide guidance and support in building an impactful practice.

Keywords: community relations and development, $R E I P P P P$, community benefit, project implementation, social performance

\section{Highlights}

- South Africa is implementing a unique version of pro-poor renewable energy policy.

- Industry and local communities and government need to build quality relationships to successfully implement the policy requirements.

- The policy and practice ignores established community development traditions and frameworks.

- Existing knowledge grounded in South African practice and policy experience can guide the sector's understanding of and vision for development.

Journal of Energy in Southern Africa 28(1): 35-44

DOI: http://dx.doi.org/10.17159/2413-3051/2017/v28i1a1592

Published by the Energy Research Centre, University of Cape Town ISSN: 2413-3051 http://journals.assaf.org.za/jesa

Sponsored by the Department of Science and Technology

\footnotetext{
* Corresponding author: Tel: +27 (0)79 9361157

Email: wlkhol001@my.uct.ac.za
} 


\section{Introduction}

South Africa, for the first time in its history, is feeding the national electricity grid with electricity generated through utility-scale renewable energy projects. The Renewable Energy Independent Power Producer Procurement Programme (REIPPPP) drives this change and also requires private energy companies to commit resources to alleviate local socio-economic needs. The programme is organised in procurement rounds. Six rounds have been issued to date, resulting in $6376 \mathrm{MW}$ of electricity being procured from 102 renewable independent power producer (IPP) projects across the country. In September 2016, the entire programme was valued at R194.1 billion. At that point, 51 IPPs were connected to the national grid, providing a total of 2 $738 \mathrm{MW}$ of electricity generation capacity (IPP Office, 2016).

Project stakeholders on the ground are still grappling with how to implement sustainable development initiatives, while government and industry bodies already celebrate the programme as a success for its energy and development achievements, (Wlokas et al. 2012; Baker \& Wlokas 2014; Wlokas 2015). South Africa has a rich history of theoretical and practical community development knowledge and experience (Hart 2012). Theoretical traditions as well as practice frameworks tend to guide policy design and programme implementation, with a mix of radical participatory approaches as advanced by the non-governmental tradition of community development or more conventional welfare approaches as taught in South Africa's schools of social work and development practice, and diffused by many government-led community development work initiatives. The REIPPPP, however, does not make reference to any of this. Lack of policy alignment is obvious not only to policy analysts but also to development practitioners on the ground.

This investigation draws on primary interview data and secondary information. Interviews included formal and informal research conversations with renewable energy project stakeholders (local government, energy companies, and community representatives) that were conducted in the context of the lead author's $\mathrm{PhD}$ research during 2014-2015. Secondary information comprised industry workshop reports and academic literature on renewable energy, community development and companycommunity relations and development.

It is argued that that existing community development knowledge and experience, which is overlooked by the REIPPPP, provides a rich resource in support of good practice development amongst the REIPPPP-concerned stakeholders in government, industry and communities. It is shown that, based on reports of multi-stakeholder workshops, the implementation discourse amongst REIPPPP stakeholders, through increased experiences on the ground as well as gentle learning space facilitation, has already grown into a greater appreciation of the non-negotiable good practice principles associated with community development. Hence, there is ground to expect that the developmental impacts of community renewables might outperform the achievements of the extractives sector in times to come.

The article defines the concept of community renewables, large-scale renewable energy projects that benefit local communities, in the international and South African contexts. The paper compares international research results on community benefits through such projects with the emerging evidence from REIPPPP implementation. Further, we introduce some of the orthodox community development traditions, frameworks and good practice ideas applicable in South Africa. Finally, we formulate concrete suggestions for REIPPPP stakeholders on how to adopt the theoretical and practical lessons.

\section{Community renewables globally and in South Africa}

Renewable energy projects, generating supply for national electricity grids, commonly engage with socio-economic needs of their host communities. Projects create benefits, beyond the employment and macro-economic impacts associated with plant construction and contribution of the plant to regional or national energy security. In Britain such benefits appear in different forms: for example, conventional economic benefits (manufacturing, land rental), financial benefits to local communities (ownership investment, cheaper electricity), in-kind contribution to local assets (visitor facilities), provision of other local services (educational visits), and/or involvement in the project development process (liaison activities) (Munday et al. 2011). Table 1 outlines the categories in more detail.

The importance of community involvement and benefits in the implementation of large-scale energy plants is emerging as a new field of research in Europe and, slowly, also in other countries. Existing research provides further insights about how renewables companies relate to communities and local development. These studies draw on case studies, interviews and surveys from Europe. Present research investigates the process and outcome of community wind projects (Walker \& Devine-Wright 2008), conditions determining local impact of renewables projects (del Río \& Burguillo 2009), the importance of trust (Walker et al. 2010), opportunities for rural development associated with community benefits of wind farms (Munday et al. 2011), the role and challenges of community ownership and investment (Haggett \& Aitken 2015), the role of community benefits in the acceptance of offshore wind farms (Walker et al. 2014; Cowell et al. 2011), as well as investigating evidence in support 
Table 1: Categories of community benefits in the context of Britain (Community Viewfinder, 2007; DTI, 2005; in Munday et al, 2011).

Conventional economic benefit:

- Using locally manufactured content, and local contractors for construction, operation and maintenance

- Land rental income to landowners and any royalties

- Local business rates and/or taxes

Flows of financial benefits to local communities:

- Some form of ownership/investment in the project among local people, either as equity or a form of profit share

- Some form of community fund, with lump sum and/or annual payments, either focussed on specific purposes (such as energy efficiency) or more open-ended

- Cheaper electricity

- Sponsorship of local events

Contributions in kind to local assets and facilities:

- To landscape and ecological enhancement measures, perhaps that mitigate or compensate for any environmental costs caused by the wind farm.

- To tourism/visitor facilities

Provision of other local services:

- Educational visits of other educational programmes

Involvement in the development process:

-Various forms of liaison activity

of community ownership (Slee 2015). Slee (2015) suggests that there remains substantial need for further research into a range of topics associated with community ownership, benefits and capacity, indicating that this field of enquiry requires increased attention not only in emerging renewable energy countries, but even in mature renewables environments like the UK and Germany.

In this context. the term community renewables refers to large-scale renewable energy projects that engage with communities around the project site about socio-economic needs and opportunities. The engagement can be deliberate on the side of the project implementers or government policy, but it can also be the result of socio-political necessity. The World Wind Energy Association (WWEA) coined a very similar term: community power. Community power projects have to fulfil at least two of these three criteria (WWEA 2011):

1. Local stakeholders own the majority or all of a project: A local individual or a group of local stakeholders, whether they are farmers, cooperatives, independent power producers, financial institutions, municipalities, and schools, own, immediately or eventually, the majority or all of a project.

2. Voting control rests with the community-based organisation: The community-based organisation made up of local stakeholders has the majority of the voting rights concerning the decisions taken on the project.

3. The majority of social and economic benefits are distributed locally: the major part or all of the social and economic benefits are returned to the local community.
None of the renewable energy projects in South Africa's REIPPPP qualify as community power projects, despite government's deliberate effort to include communities as mandatory beneficiary and shareholders into the programme design. The procurement programme requires projects to share revenue and ownership with local communities in a 50-kilometre radius around project sites (Department of Energy 2011), but there is no focus on ownership per se, rather an emphasis on limited ownership and economic benefit opportunities, combined with a capped local redistribution of profits with potential for social, welfare and developmental to local communities. The policy and associated tender documents stipulate quantitative targets for investments into socio-economic and enterprise development $(1-1.5 \%$ and up to $0.6 \%$ of total project revenue) and also identify a minimum community shareholding threshold $(2.5 \%$ of project shareholding). Strategic guidance as to what these investments should ultimately achieve is only recently available, in the form reproduced in Table 2 below, which the procuring Department of Energy and the IPP office published in 2015. It outlines the expected alignment between the REIPPPP criteria and the National Development Plan.

The REIPPPP applies technocratic language, referring to socio-economic development (SED), enterprise development (ED) and local ownership, with companies tending to adopt these terms. Commonly, local government understands these to feed into, or at least relate to, their 'local economic development' efforts. Social performance consultants, hired by energy companies, need to translate the REIPPPP terminology into language that is 
understood by ordinary citizens in communities across the country. Thus, consultants often refer to 'community benefits' or 'local community development'. Communities and community development practitioners discuss these elements in the context of 'community development'. This article refers to 'community benefits' and focuses specifically on the gaps between the provision for community benefit, and in particular SED, and the practices that might best give effect to these intentions.

The table stipulates that REIPPPP's SED investments shall contribute towards sustainable rural communities and sustainable human settlements. Government's expectation of SED investments presents a mechanical view of change and development, suggesting that financial investments into education, health and infrastructure will lead to improved wellbeing of previously disadvantaged individuals and communities, whatever the conditions under which the intervention occurs. Enterprise development is targeted to support decent employment through inclusive growth and also sustainable rural communities. Enterprise development reflects another development paradigm, associating strengthened free market forces with the alleviation of poverty. A third development intent can be associated with the local ownership requirement. Government indicates that local community ownership in REIPPPP projects shall benefit decent employment through inclusive growth, sustainable rural communities, creating a better and safer South Africa, as well as nationbuilding and social cohesion (IPP Office 2015). Table 2 outlines the NDP outcomes and primary focus and individual REIPPPP contributions in further detail. It would be fascinating to draw the respective theories of change, underlying each of these paradigms in the REIPPPP context - an exercise worth considering as the industry grows and develops a clearer vision for its development contribution.

To date, the stipulated community benefit requirements have resulted in significant financial commitments towards community benefits. After four bid window rounds that approved a total of 92 wind, solar, hydro, landfill gas and biomass projects, industry's collective commitments total over R70 billion (SED: R19.2 billion; ED: R6 billion; local ownership: R50.1 billion) (IPP Office 2015). Table 3 presents the commitments per criteria, for the country as a whole and the individual amounts for the Northern, Eastern and Western Cape provinces, which host most REIPPPP projects.

The policy provides a unique opportunity for the prominent and growing green economy player, the renewable energy industry, to position itself as significant development contributor in the South African landscape. But what, if not policy, can guide industry to how to conduct itself in the challenging task of to implementing community development?

Table 2: Alignment of NDP outcomes and REIPPPP bid obligations (adopted from IPP Office 2015a).

\begin{tabular}{|c|c|c|}
\hline NDP outcomes & Primary focus & $\begin{array}{l}\text { REIPPPP bid categories } \\
\text { addressing specific outcome }\end{array}$ \\
\hline Outcome 4 & $\begin{array}{l}\text { Decent employment through inclusive economic } \\
\text { growth }\end{array}$ & $\begin{array}{l}\text { Job creation } \\
\text { Enterprise development } \\
\text { Ownership } \\
\text { Preferential procurement } \\
\quad \text { Local content } \\
\end{array}$ \\
\hline Outcome 5 & $\begin{array}{l}\text { A skilled and capable workforce to support } \\
\text { an inclusive growth }\end{array}$ & $\begin{array}{c}\text { Job creation } \\
\text { Management control }\end{array}$ \\
\hline Outcome 7 & $\begin{array}{l}\text { Vibrant, equitable sustainable rural communities } \\
\text { contributing towards food security for all. } \\
\text { Reduction of rural unemployment rate. } \\
\text { Increased access to quality infrastructure and services, } \\
\text { specifically education, healthcare and public transport }\end{array}$ & $\begin{array}{c}\text { Job creation } \\
\text { Socio-economic development } \\
\text { Ownership } \\
\text { Enterprise development }\end{array}$ \\
\hline Outcome 8 & $\begin{array}{l}\text { Sustainable human settlements and improved } \\
\text { quality of household life }\end{array}$ & Socio-economic development \\
\hline Outcome 10 & $\begin{array}{l}\text { Protect and enhance environmental assets and } \\
\text { natural resources } \\
\text { Reduced total emissions of } \mathrm{CO}_{2} 34 \% \text { reduction } \\
\text { from business as usual scenarios. }\end{array}$ & $\begin{array}{l}\text { Results from power generation } \\
\text { from 'clean' energy sources } \\
\text { (a consequence of Outcome 6) }\end{array}$ \\
\hline Outcome 11 & $\begin{array}{l}\text { Create a better South Africa, contribute to a } \\
\text { better and safer Africa in a better world } \\
\text { Increased FDI: R230 billion by } 2019 \\
\text { (from baseline of R40 billion in } 2013 \text { ) }\end{array}$ & Ownership \\
\hline Outcome 14 & $\begin{array}{l}\text { Nation-building and social cohesion } \\
\text { Disability and gender equality } \\
\text { Equal opportunities and redress }\end{array}$ & $\begin{array}{l}\text { Preferential procurement } \\
\text { Job creation } \\
\text { Ownership }\end{array}$ \\
\hline
\end{tabular}


Table 3: Committed community funds per province (BW1 to 4, 1S2) (IPP Office reports published December 2015).

\begin{tabular}{lcccc}
\hline Criteria & Northern Cape & Eastern Cape & Western Cape & South Africa \\
\hline $\begin{array}{l}\text { Socio-economic } \\
\text { development* }\end{array}$ & $\begin{array}{l}\text { R11.9 billion } \\
\text { (R10.2 billion) }\end{array}$ & $\begin{array}{c}\text { R4.5 billion } \\
\text { (R3.9 billion) }\end{array}$ & $\begin{array}{l}\text { R1.0 billion } \\
\text { (R0.7 billion) }\end{array}$ & R19.2 billion \\
\hline Enterprise development & R3.1 billion & R1.2 billion & R0.1 million & R6 billion \\
\hline Local ownership & R29.3 billion (net & R14.5 billion (net & R2.5 billion(net & R50.1 billion (net \\
& income R18.3 billion) & income R7.4 billion) & income R1.6 billion) & income R20.9 billion) \\
\hline * Commitments vary; the amounts in brackets indicate the committed amount for local communities within a 50 km radius.
\end{tabular}

\section{The REIPPPP overlooks a rich community development history in South Africa}

As stated in the introduction to this paper, one of the issues for the renewable energy investments in community development is what appears to be a lack of attention to what has been learned for many decades in South Africa and beyond about successful community-company relations specifically, and also community development generally (Lochner et al. forthcoming). The mining industry is also known for succumbing to a lack of reflection about knowledge and practice, attributing it to tight timelines and budgets (Owen \& Kemp 2012). In an attempt to categorise the community relations and development practices across minerals companies (within the extractives sector), Owen and Kemp (2012) preliminarily grouped them into five frames and methods, including public relations approach, risk mitigation and 'opportunity' orientation, needs-based approach and the five capitals model. Common amongst these, is a limiting tendency "to polarize discussion by focusing on what "reputation," "risks," "needs," "capitals," "rights," or "resources" mean to one party, without offering a conceptual mechanism through which to mediate these understandings' (Owen \& Kemp 2012). It is too early in the life of the renewables industry, at least in South Africa, to distinctly seek out practice frames. Only about half of the approved REIPPPP projects (around 45) are operational at this point, with others in various stages of development. Thus, the contribution this article offers is a timely reflection in anticipation and preparation of the imminent practice development within the renewables sector

\section{Locating community development within the broader literature}

There are many community development frameworks or approaches (the two terms are used interchangeably here) which have been developed, articulated and diffused within the academic literature. Examples include: 'human rights from below' (Ife, 2009), a networking approach (Gilchrist, 2004), a critical approach (Ledwith, 2005), dialogical community development (Westoby and Dowling, 2009/2013), radical empowerment (Craig and Mayo, 1995), community organising (Alinsky, 1969; 1971), human-scale development (Max-
Neef, 1991), and so forth. Each framework considers community development practice through different lenses, and highlights different aspects of theory that can provide indications for practice. While these are not examined here, readers can draw on the references to explore the particulars of each one. Within South Africa, however, the predominant approaches can be understood through a policy-oriented lens and an organisationally-diffused lens. Each is explained.

\section{Policy-oriented frameworks}

There have been at least four development frameworks that the post-1994 South African government has adopted in its effort to improve the lives of its citizens. These approaches have been identified within the draft National Community Development Policy Framework - and most recently by Luka and Maistry (2012) - as the income, basic needs, social exclusion and the sustainable livelihoods perspectives. Each of these frameworks has been operationalised in terms of pragmatic initiatives, programmes and projects, and has also been deeply influenced by the way in which community development practitioners, particularly those employed by the state, understand their work.

The income framework was grounded on the logic of economic poverty, reasonably arguing that people are recognised as poor if they fall below a defined income line or if they do not hold incomebased employment. Despite the limits of such a frame, interventions based on income have been a significant part of the government's approach to poverty. For example, its social protection policy, operationalised primarily in social welfare grants, but also in anti-poverty jobs and wages, has been diffused through various policy instruments including the Growth, Employment and Redistribution Plan, social assistance and the Extended Public Works Programme.

The basic needs framework focused assistance to the poor in supporting their access to sanitation, security, clean water, shelter, education, appropriate clothing, health and other such necessities. South Africa, primarily through its Reconstruction and Development Programme and accompanying programmes, has attempted to operationalise this perspective. Evaluations indicate that the impacts have 
remained largely patchy, uncoordinated, disorganised, poorly integrated, lacking consistency or focus and incoherent. However, such a framing of development policy and programmes remains important considering the level of marginalisation from access to such basic needs.

The social exclusion framework seeks to seal the cracks of deprivation, vulnerability and inequality that can coexist with wealth creation and adequate social welfare systems. In South Africa, the key policy instrument situated within this framework is the Bill of Rights within the Constitution (Act 108 of 1996). This seeks to address the systemic and structural results of racism, sexism, geographical isolation as well as cultural and political exclusionism. Other relevant policy instruments include the South African Human Rights Commission and the Commission on Gender and Equality.

Finally, the sustainable livelihoods framework focuses practice on the requirement for ordinary people and communities to be assisted, through the construction and strengthening of an appropriate 'asset base', enabling them to proactively identify, define and practice particular strategies for coping with their conditions of poverty, vulnerability and hardships. This is the key policy and programme 'framing' on current discourses of community development at the time of writing. It is central to the newly developed community development policy framework as well as many initiatives of the Social Development Department.

Such policy-oriented frameworks frequently determine the direction of programmes and practice, at least in theory. As Westoby reported in his research, 'Often when interviewing community development practitioners it was easy to discern the influence of such frameworks and their accompanying languages. People would often talk about income, needs, rights or assets ... it was assumed knowledge' (Westoby, 2014).

\section{Organisationally-diffused frameworks - 'the big four'}

Many community development practitioners are however, primarily influenced less by these policyoriented frameworks, or by the academic literature, than by what can be understood as organisationally-diffused frameworks. Practitioners used some of the words of the policy frameworks, but their actual practice is often more aligned to those frames diffused through the organisations they work for. The most commonly occurring organisationally diffused frameworks were as follows:

- The framework of community-driven or community-led development, internationally championed particularly by the World Bank (Everatt \& Gwagwa, 2005). Within South Africa this approach is being used by NGOs such as Khanya-acidd. Other examples of this would be the people's-housing process - ideally a selfhelp and community-driven approach for delivering housing to people.

- Rights-based community development, again diffused internationally by numerous international NGOs (e.g. ActionAid) and some United nations programmes, are being used by NGOs such as Institute for Democracy in South Africa.

- The asset-based community development (ABCD) approach, researched and internationalised by the Coady Institute, has also been drawn upon within South Africa (Schenck, Nel \& Louw, 2012: 62). For example, Susan Wilkinson-Maposo (2008) writes about the work in Jansenville in the Eastern Cape as an example of a community development process drawing on the ABCD approach.

- The sustainable livelihoods approach (SLA), diffused by the UK DFID and drawing on the research and writing of Robert Chambers, is used extensively by the Department of Social Development, particularly within their Community Development Practitioner Programme. Drawing on the training of Khanya-acidd they have been integrating the SLA framework as a tool of analysis within a community-based planning approach.

These four 'big' frameworks dominate the discursive field within South Africa and most community workers are familiar with the language of one or several of these organisationally-diffused frameworks.

The REIPPPP does not recognise or appreciate this knowledge, either through outlining even a broad vision or giving guiding principles for the implementation of the stipulated community benefits. In fact, as discussed above, the three distinct community investments (SED, ED and local ownership) represent if not contradictory then certainly diverse notions of development. Within the freedom to interpret appropriate practice as found fit, which is commonly made use of by the energy company that administers the community investments and carries the responsibility of the quarterly spend and reporting, industry conversations are converging towards greater appreciation of principled community development work.

\section{Emerging evidence of renewable energy industry practice in communities}

Research in South Africa on the community development, company-community relations or broader termed social performance in REIPPPP is in its infancy. Five years into the programme, the research landscape is changing as the first international research funding calls (e.g. from DANIDA) become available for academic research of REIPPPP and its various community implications. 
Table 4: Practice frameworks of community development in South Africa (Westoby 2014; Luka \& Maistry 2012).

\begin{tabular}{|c|c|c|c|c|}
\hline $\begin{array}{l}\text { Policy-oriented } \\
\text { frameworks }\end{array}$ & $\begin{array}{l}\text { Income } \\
\text { framework }\end{array}$ & $\begin{array}{l}\text { Basic needs } \\
\text { framework }\end{array}$ & $\begin{array}{l}\text { Sustainable liveli- } \\
\text { hood approach/ } \\
\text { framework }\end{array}$ & $\begin{array}{l}\text { Social exclusion } \\
\text { framework }\end{array}$ \\
\hline Focus & Economic poverty & $\begin{array}{l}\text { Access to sanitation, security, } \\
\text { clean water, education, app- } \\
\text { ropriate clothing, health, etc }\end{array}$ & $\begin{array}{l}\text { Construction and strength- } \\
\text { ening of appropriate } \\
\text { 'asset base' }\end{array}$ & $\begin{array}{l}\text { Deprivation, vulnerability, } \\
\text { inequality }\end{array}$ \\
\hline $\begin{array}{l}\text { International and } \\
\text { local examples }\end{array}$ & $\begin{array}{l}\text { Social protection policy } \\
\text { and welfare grants, } \\
\text { GEAR, ASGISA, EPWP }\end{array}$ & RDP policy & $\begin{array}{l}\text { Community development } \\
\text { Policy framework, Social } \\
\text { Development Department }\end{array}$ & $\begin{array}{l}\text { Bill of Rights, SA Human } \\
\text { Rights Commission, Commis } \\
\text { sion on Gender and Equality }\end{array}$ \\
\hline $\begin{array}{l}\text { Organisation- } \\
\text { diffused } \\
\text { frameworks }\end{array}$ & $\begin{array}{l}\text { Community-driven and } \\
\text { community-led development }\end{array}$ & $\begin{array}{l}\text { Rights-based com- } \\
\text { munity development }\end{array}$ & $\begin{array}{l}\text { Asset-based com- } \\
\text { munity development }\end{array}$ & $\begin{array}{l}\text { Sustainable livelihood } \\
\text { approach/ framework }\end{array}$ \\
\hline Focus & $\begin{array}{l}\text { Self-help, community- } \\
\text { driven approaches }\end{array}$ & & & \\
\hline $\begin{array}{l}\text { International and } \\
\text { local examples }\end{array}$ & $\begin{array}{c}\text { World Bank, Khanya } \\
\text {-acidd, People's Housing } \\
\text { Process }\end{array}$ & $\begin{array}{c}\text { Action Aid, UN } \\
\text { programmes, IDASA }\end{array}$ & Coady Institute & $\begin{array}{c}\text { UK DfiD, Robert Chambers, } \\
\text { Community Development } \\
\text { Practitioner Programme }\end{array}$ \\
\hline
\end{tabular}

Table 5: Community benefit workshops hosted and analysed 2013-2016.

\begin{tabular}{|c|c|c|c|c|c|}
\hline & Workshop topic & No. of participants & Workshop date & Organisers & Facilitator \\
\hline 1. & $\begin{array}{l}\text { Addressing the challenges in } \\
\text { fulfilling the community benefit } \\
\text { requirements in the REIPPPP }\end{array}$ & 22 & 7 March 2013 & $\begin{array}{c}\text { Energy Research Centre (ERC) } \\
\text { University of Cape Town }\end{array}$ & Sue Soal \\
\hline 2 & $\begin{array}{l}\text { Implementing local community dev- } \\
\text { elopment benefits in the REIPPPP } \\
\text { - inspiring good practice }\end{array}$ & 26 & 12 July 2013 & ERC & Sue Soal \\
\hline & $\begin{array}{l}\text { anaging community unrest resulting from } \\
\text { itical lobbying for municipal elections } 2016\end{array}$ & 26 & 26 April 2016 & $\begin{array}{l}\text { SA Wind Energy Association, } \\
\text { SA Photovoltaic Industry } \\
\text { Association (SAWEA, SAPVIA) }\end{array}$ & Sue Soal \\
\hline 7. & $\begin{array}{l}\text { Supporting sound community trusts } \\
\text { establishment, governance and operation }\end{array}$ & 60 & 23 May 2016 & SAWEA, SAPVIA & Sue Soal \\
\hline 5. & Collaboration for scale and impact & 42 & 26 August 2016 & SAWEA, SAPVIA & eter v d Brc \\
\hline
\end{tabular}

Initial research findings, presented in working papers (Wlokas et al. 2012; Baker \& Wlokas 2014; Mcewan 2017), student thesis projects (Bode 2013; Tait 2012) and non-governmental research (Wlokas 2015; Tait et al. 2013; Electricity Governance Initiative 2014), share common views on the challenges associated with the programme's community benefit requirements and resulting need for greater attention to planning, monitoring and evaluation of resulting impacts. Thus, there is ample scope and need to advance research to support the successful implementation of renewable energy in social contexts of poverty and inequality. Accounts of the current state of play in the sector provide guiding insights for future research efforts in support of sustainable corporate community development practice.

Since the inception of REIPPPP in 2011, various multi-stakeholder workshops provided platforms for the sector to exchange and reflect on the emerging experiences made in the design and implementation of community benefits. Two authors of this paper were involved in five such workshops between 2012 and 2016 (see Table 5). Their involvement ranged from overall hosting and facilitating to co-hosting and report-writing. The workshop reports are insightful accounts of the sector's learning (Wlokas \& Soal 2016a; Wlokas 2016; Wlokas \& Soal 2016b; Energy Research Centre 2013; Wlokas et al. 2013).

Analysis of the workshop reports reveals five major trends. Firstly, there is a growing realisation of the magnitude of the challenge to implement meaningful, lasting positive change through development interventions and funding in communities. Secondly, the absence of government oversight and guidance in support of quality and direction of interventions and funding allocation results in a wide range of community engagement practices and development initiatives. Thirdly, it is possible to report compliance on all community investments without creating much impact on the ground. Real 
change requires companies to attend with time and sensitivity to the place- and people-specific conditions for development. Fourthly, these determining conditions are dynamic and demand responsive capacity from companies and communities to maintain quality relationships over time. Finally, the workshops repeatedly identified a need for processes and structure (through an independent entity for example, community trust association, or similar) to be established to support the sector's community development work over time, allowing lessons to be shared amongst and across communities, industry and government.

\section{How REIPPPP can adopt theoretical and practice lessons}

In Section 3 it was argued that there is a long tradition of community development practice that can be drawn on for lessons learned by the REIPPPP industry. There is no need to learn by trial and error, or to reinvent the whole field of community development as a specialised and skilled terrain of practice. There is merit, however, in drawing on the insights from the field of community development and those emerging out of the REIPPPP's experience, notably the insight that there is no 'silver bullet', no single method for community development that will work in all circumstances. Whatever modality, sector or emphasis is ultimately chosen, some basic practices reveal themselves as essential: relationship, observation, listening, consultation, responsivity, adaptability,

This is not to say that all past and present experiences of community development can be drawn upon to distill good practice. Therefore it is useful to draw on research that has already distilled such good practice, and a valid starting point is the work by one of the authors of this paper - Westoby's (2014) case studies from South Africa. Drawing on five closely studied examples of community development Westoby identifies the practices shown in Table 6 as crucial for 'creating the conditions' that support effective practice. The 'creating the conditions' clause alludes to the complexity of social phenomenon in which there is no guarantee of 'success' in any social intervention. However, such studies show what gives the best chances - hence 'optimal conditions'. It is worth noting the overlap, in lessons and tone, between Westoby's work and those emerging out of the reflections of those in the renewables sector, as detailed in the accounts above. Table 6 summarises key practices, and readers can learn about practices in detail through the primary source.

Kemp's work on extractive industry-community relations can also be useful, again highlighting what seems to be working best in such corporate-community relations. Strongly promoted is the assetbased community development (ABCD) approach. This approach, tailored to the community relations needs of the extractive industries, allows for 'an understanding of what can be done in a community to improve its standing, how it can be done, and with which combination of individuals and assets' to emerge (Owen \& Kemp 2012). ABCD, and its version tailored to the mining industry, is just one example of the existing work, drawing on decades of experience, which industries with less entrenched social performance legacies, like renewable energy, fisheries and forestry, can and should tap into. The role of academia, in the form of engaged scholarship or transdisciplinary research, is critical in mak-

Table 6: Community development practices collected in South Africa (Westoby 2014).

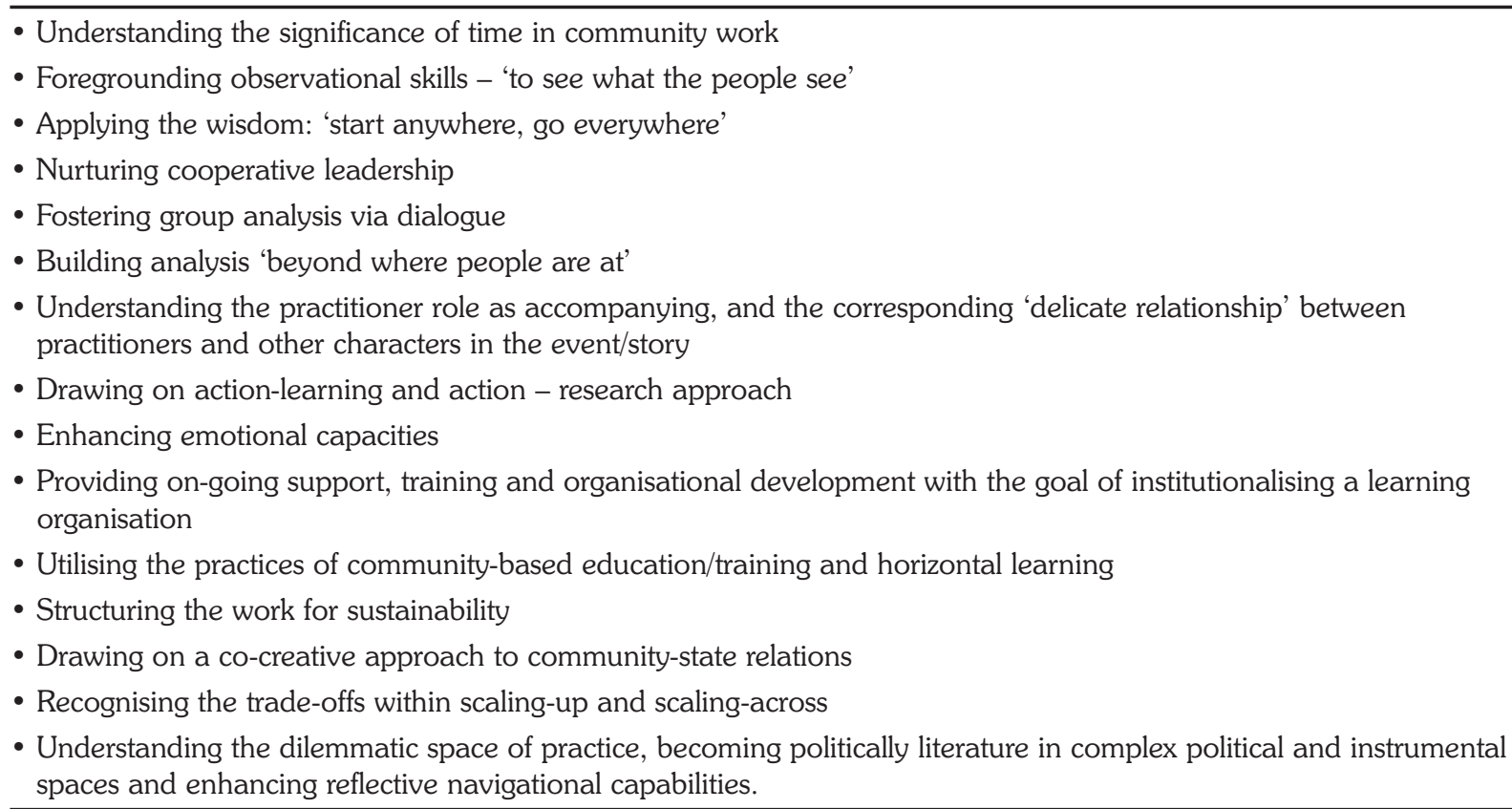


ing this knowledge available and conveying it to the relevant stakeholders through training, publications and practice examples.

\section{Conclusions}

In this article we introduced the South African case study, the REIPPPP programme that is implementing a unique version of pro-poor renewable energy policy. The programme promotes three avenues of potential (community) developmental impact, requesting energy projects to implement all three within the context of each individual power plant. The alignment of the community development requirements with the existing policy and development context is open for interpretation, at best. While promoting community benefit or development it nevertheless ignores established community development traditions and frameworks, thus allowing industry to determine its qualitative impact in local communities.

The financial resources associated with the community requirements are significant, making it necessary for industry, local communities and government to build quality relationships to successfully convert these investments into sustainable developmental impacts. In this context, the industry and concerned and affected stakeholders within government, financial institutions and civil society avidly participate in topical conversations and workshops.

The insights of five such multi-stakeholder workshops were highlighted. Reviewing the workshop reports led to the apprehension that the implementation discourse amongst REIPPPP stakeholders, through increased experiences on the ground as well as gentle learning-space facilitation, has already grown into a greater appreciation of the non-negotiable good practice principles associated with community development. Hence, and with continued reflection, learning and adaptation, there is ground to expect that the developmental impacts of community renewables might outperform the achievements of the extractives sector in times to come. This is an emerging field of research in which engaged research can play a key role, if designed to systematically analyse and facilitate resulting learnings about the practices employed in the implementation of large-scale renewables plants, in South Africa and internationally.

In conclusion, we urge that this momentum and willingness to learn amongst REIPPPP stakeholders needs to be fostered. Existing knowledge grounded in South African practice and policy experience can guide the sector's development understanding and vision, and academia's role and responsibility lies in supporting this through engaged and transdisciplinary research.

\section{Acknowledgements}

This paper draws on research funded by the Volkswagen Foundation, and the National Research Foundation of South Africa.

\section{References}

Alinsky, S. 1964. Reville for radicals. Chicago: University of Chicago Press.

Alinsky, S. 1971. Rules for radicals: A pragmatic primer for realistic radicals. New York: Random House.

Baker, L. and Wlokas, H.L. 2014. South Africa's Renewable Energy Procurement : A new frontier South Africa's Renewable Energy Procurement : A New Frontier, Energy Research Center, University of Cape Town, South Africa.

Bode, C.C., 2013. An analysis of collective ownership models to promote renewable energy development and climate justice in South Africa. Thesis, North West University.

Cowell, R.J.W., Bristow, G.I. and Munday, M.C.R. 2011. Acceptance, acceptability and environmental justice: the role of community benefits in wind energy development. Journal of Environmental Planning and Management 4(54): 539-557. Available at: http://dx.doi.org/10.1080/09640568.2010.521047.

Del Río, P. and Burguillo, M. 2009. An empirical analysis of the impact of renewable energy deployment on local sustainability. Renewable and Sustainable Energy Reviews, 13(6-7): 1314-1325.

Department of Energy. 2011. Request for qualification and proposals for new generation capacity under the IPP Procurement Programme. Part C: Evaluation Criteria

Electricity Governance Initiative. 2014. Renewable Energy Independent Power Producer Programme Review 2014, Research Report, Cape Town, South Africa. Available at: http://www.egi-sa.org.za/wp-content/uploads/2011/10/EGI-REI4P-review-2014pdf.pdf.

Energy Research Centre. 2013. Addressing the challenges in fulfilling the community benefit requirements in the RE IPPPP. Report back on consultative workshop held on 7 March 2013, University of Cape Town, South Africa.

Haggett, C. and Aitken, M. 2015. Grassroots energy innovations: The role of community ownership and investment. Current Sustainable/Renewable Energy Reports 2(3): 98-104. Available at: http://link. springer.com/10.1007/s40518-015-0035-8.

IPP Office. 2015. Independent Power Producers Procurement Programme (IPPPP). Available online at: https://www.ipp-projects.co.za/Home/Publications.

IPP Office. 2016. Independent Power Producers Procurement Programme (IPPPP): An overview as at 30 September 2016. Available online at: https://www.ipp-projects.co.za/Home/Publications.

Lochner, M., Wlokas, H.L., de Groot, J., Dube, N., Scheba, A. (Forthcoming). Renewable energy and local development: Seven lessons from the mining industry. Development Southern Africa.

Luka, S. and Maistry, M., 2012. The institutionalization of community development in democratic South Africa. In Conference Proceedings Towards Carnegie

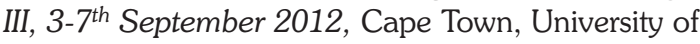


Cape Town. Available online at: http://carnegie3.org. za/docs/papers/158 Luka The\%20institutionalization \%20of\%20Comdev\%20in\%20a\%20democratic\%20 SA.pdf

McEwan, C., 2017. Spatial processes and politics of renewable energy transition: Land, zones and frictions in South Africa. Political Geography, 56:1-12. Available at: http://dx.doi.org/10.1016/j.polgeo. 2016.10.001.

Munday, M., Bristow, G. and Cowell, R. 2011. Wind farms in rural areas: How far do community benefits from wind farms represent a local economic development opportunity? Journal of Rural Studies, 27(1): 1-12. Available at: http://linkinghub.elsevier. com/retrieve/pii/S0743016710000549 [Accessed August 6, 2014].

Owen, J.R. and Kemp, D. 2012. Assets, capitals, and resources: Frameworks for corporate community development in mining. Business and Society, 51(3): 382-408. Available at: http://bas.sagepub.com/ cgi/doi/10.1177/0007650312446803 [Accessed August 18, 2014].

Slee, B. 2015. Is there a case for community-based equity participation in Scottish on-shore wind energy production? Gaps in evidence and research needs. Renewable and Sustainable Energy Reviews 41: 540-549. Available at: http://dx.doi.org/10.1016/ j.rser.2014.08.064.

Tait, L. 2012. The potential for local community benefits from wind farms in South Africa. University of Cape Town, Thesis, University of Cape Town.

Tait, L., Wlokas, H.L. and Garside, B., 2013. Making communities count, International Institute for Environment and Development, London. Available at: http://pubs.iied.org/16043IIED.html.

Walker, B.J., Wiersma, B. and Bailey, E. 2014. Community benefits, framing and the social acceptance of offshore wind farms: An experimental study in England. Energy Research and Social Science 3: 46-54. Available at: http://linkinghub.elsevier.com/ retrieve/pii/S2214629614000814.

Walker, G., Devine-Wright, P., Hunter, S., High, H., Evans, B., 2010. Trust and community: Exploring the meanings, contexts and dynamics of community renewable energy. Energy Policy 38(6): 2655-2663.

Walker, G. and Devine-Wright, P., 2008. Community renewable energy: What should it mean? Energy Policy 36(2): 497-500. Available at: http://linkinghub.elsevier.com/retrieve/pii/S030142150700473 9 [Accessed July 9, 2014].

Westoby, P. 2014. Theorising the practice of community development. A South African perspective, Surrey (UK): Ashgate.

Wlokas, H., 2015. A review of the local community development requirements in South Africa's renewable energy procurement programme, WWF South Africa, Cape Town. Available at: http://awsassets. wwf.org.za/downloads/local_community_development_report_20150618.pdf.

Wlokas, $\bar{H}$., 2016. Economic development in REIPPPP: Collaboration for scale and impact. Roundtable report, Transformation Energy Trust, Cape Town, South Africa. Available at: http://www.sawea.org.za/ index.php/resource-library/round-table-conversationseries.

Wlokas, H. and Soal, S., 2016a. Economic development in REIPPPP Managing community unrest: Roundtable report, Transformation Energy Trust, Cape Town, South Africa. Available at: http://www. sawea.org.za/index.php/resource-library/round-tableconversation-series.

Wlokas, H. and Soal, S., 2016b. Economic development in REIPPPP Supporting sound community trusts, Transformation Energy Trust, Cape Town, South Africa. Available at: http://www.sawea.org.za/ index.php/resource-library/round-table-conversationseries.

Wlokas, H., Tait, L. and Soal, S., 2013. Implementing local community development benefits in the RE IPPPP - inspiring good practice. Report back on a consultative workshop held on 12 July 2013, University of Cape Town, South Africa.

Wlokas, H.L., Boyd, A. and Andolfi, M., 2012. Challenges for local community development in private sector-led renewable energy projects in South Africa: an evolving approach. Journal of Energy in Southern Africa 23(4): 46-52.

World Wind Energy Association, 2011. WWEA press release: WWEA highlights community power. Not available online. 